\title{
MALAYSIAN CHINESE LANGUAGE NEWSPAPERS AND NATIONAL IDENTITY: A STUDY OF THE ROLES OF SIN CHEW DAILYIN CHINESE CULTURAL PRESERVATION AND NATION BUILDING
}

\author{
Ng Miew Luan ${ }^{*}$ and Lee Yuen Beng ${ }^{2}$
}

${ }^{1}$ Faculty of Communication and Creative Design, SEGi University, Selangor, MALAYSIA

${ }^{2}$ School of Communication, Universiti Sains Malaysia, Pulau Pinang, MALAYSIA *Corresponding author: miewluan@gmail.com

Published online: 27 April 2018

To cite this article: $\mathrm{Ng}, \mathrm{M}$. L. and Y. B. Lee. 2018. Malaysian Chinese language newspapers and national identity: A study of the roles of Sin Chew Daily in Chinese cultural preservation and nation building. Kajian Malaysia 36(1): 63-103. https://doi.org/10.21315/km2018.36.1.4

To link to this article: https://doi.org/10.21315/km2018.36.1.4

\begin{abstract}
As the leading Chinese language newspaper in Malaysia, Sin Chew Daily remains focused on emphasising and preserving Chinese cultural and nationalist discourses. On one hand, Sin Chew Daily continues to play a significant role in supporting government policies such as the promotion of ethnic relations and nation-building efforts within multicultural Malaysia. On the other, as a Chinese language newspaper, Sin Chew Daily has never neglected its role in preserving Chinese culture. Using the mixed methods approach, namely content analysis as the first phase of data collection and in-depth interview as the second phase of data collection, this paper examines the agenda of Chinese cultural preservation and nation-building within the context of ethnic relations and national identity by Sin Chew Daily. Based on the relationship of the media and society, and the market and the State, this paper will argue how Chinese cultural preservation through news reporting of cultural rights and Chinese education remains the priority for Sin Chew Daily as compared to the agenda of nation-building. The findings of this study indicate that Sin Chew Daily continues to successfully play its role in representing the news of Chinese education issues, cultural and religious rights, national identity issues and news that promote good interethnic relations. However, Sin Chew Daily needs to enhance its role in establishing a constructive debate platform for the Malaysian civil society to decide on its nation-building
\end{abstract}


"formula" that is acceptable by all while clearly communicating the nation-ofintent of the Malaysian Chinese community to the ruling government.

Keywords: Chinese language newspapers, culture, nation building, ethnic relations, national identity

\section{INTRODUCTION}

In many of his public speeches, Sin Chew Daily owner, Tiong Hiew King emphasises about the importance of preserving and upholding Chinese cultural and nationalist discourses. During these speeches, Tiong also claims that Sin Chew Daily does not prioritise profits but places importance on the perseveration of Chinese culture and representing Chinese issues worldwide. ${ }^{1}$ As such, Sin Chew Daily is expected to be a social institution that bridges the ruling elite and Malaysian Chinese community. Being a vernacular newspaper in multi-ethnic Malaysia, Sin Chew Daily is also expected to carry out its "traditional role" of communicating information, leading public discourse and bridging society, and preserving culture. ${ }^{2}$ As the second largest ethnic community, the Malaysian Chinese culture is also often deemed as having to compete with the local indigenous' culture for survival. As such, Chinese cultural preservation is seen as the responsibility of the Chinese people and Chinese language newspapers.

Sin Chew Daily is currently the leading Chinese language newspaper in Malaysia in terms of circulation and readership. ${ }^{3}$ Throughout the years, Sin Chew Daily often changes its role in order to serve the different needs of its readers, the community and nation. When Sin Chew Daily (then known as Sin Chew Jit Poh) was first established in 1929, it was used as an advertising media by its Singaporean owner Aw Boon Haw and family to promote their Tiger Balm products (Kou, 2005). However, the role of Sin Chew Daily has changed especially in the context of postcolonial Malaysia. In 1982, ownership of Sin Chew Daily was taken over by Lim Kheng Kim and six years later the newspaper owned by Tiong Hiew King.

As a Chinese language newspaper in a multi-ethnic nation, it is crucial for Sin Chew Daily to be alert about issues related to ethnicity and religion (Siew, 2006). According to Siew, Chinese language newspapers encourage dialogue instead of resistance in resolving interethnic and inter-religion conflicts provoked by extremists and irresponsible politicians. As such, Sin Chew Daily aims to promote good ethnic relations and create a peaceful society while preserving the communal and cultural rights of the Malaysian Chinese.

Chinese culture preservation becomes one of the main roles played by Chinese language newspapers in Southeast Asia. Such newspapers uphold the usage of Mandarin - the medium of Chinese ethnic presses (Peng, 2005). The 
use of Mandarin, also popularly known as Chinese language, becomes a form of identification for the Chinese ethnic community while Chinese language newspapers provide a conducive environment for the Chinese to learn Chinese language. To Peng, the initiative to save and disseminate Chinese culture comes from Chinese language newspapers. This effort enables Chinese language newspapers in Southeast Asia to continue their roles in preserving Chinese culture. Chang (2005) also mentions that the Chinese in Southeast Asia are often minorities in countries they live in while their governments often do not support the practice of Chinese cultures. Chinese language newspapers then fill the void in Chinese cultural preservation and this role is always welcomed and supported by the local Chinese communities.

Sin Chew Daily has openly positioned itself as the medium to preserve the Chinese culture, as the spokesperson of the Chinese-educated community regarding issues of Chinese education and language. This position is reiterated as Tiong Hiew King publicly claims that Chinese language newspapers owned by him are not only about profits but preserving the Chinese culture and representing the Chinese around the world. ${ }^{4}$ As such, Chinese language newspapers become channels that disseminate communal demands as well as platforms to protect the communal rights of the Malaysian Chinese (Chang, 2005).

In light of this, this paper examines the roles of Chinese cultural preservation and nation building within the larger context of ethnic relations and national identity played by Sin Chew Daily. This paper will be divided into two parts: the first examines the extent to which Chinese cultural preservation becomes an important agenda for Sin Chew Daily. The second part examines to what extent ethnic relations and national identity are an important agenda for Sin Chew Daily.

\section{THE CHANGING ROLE OF CHINESE LANGUAGE NEWSPAPERS IN MALAYSIA: A BRIEF HISTORY}

In Malaysia, Chinese language newspapers or news publications has a history spanning over two centuries. In 1815, Chinese Monthly Magazine became the first Chinese-language news magazine to be published with the objective of spreading Christianity in China. As the Qing dynasty government in China prohibited the protestant mission in China, William Milne then published Chinese Monthly Magazine in Melaka. ${ }^{5}$ During the era of British colonialism, individual Englishmen published the majority of Chinese newspapers while more than 40 Englishlanguage newspapers existed in Malaya. These newspapers were produced to fulfil the commercial needs of European communities especially those in the Straits settlement and contained mainly commercial news and advertisements and had a short life span (Mohd. Dhari, 1992: 118). By the end of the 19th century however, 
the local Chinese began to publish their own newspapers, which mainly contained reprinted news and articles from newspapers of Mainland China and Hong Kong. This indicated that the Chinese communities, who were immigrants from China, still had their attachments to their homeland as the content of these Chinese language newspapers focused mainly on the political activities in China and were either in support of (Tien Nan Shin Pao 1898-1905 in Singapore and Penang Sin Pao 1895-1941) or against the monarchy (Thoe Lam Jit Poh 1904-1906, Chong Shing Yit Poh 1907-1910 in Singapore and Kwong Wah Yit Poh 1908-1910 in Burma and Penang 1910-current) (Mohd Dhari, 1992).

After the Chinese Revolution of 1911 between pro- and anti-monarchy forces, Chinese language newspapers in Malaya began to shift their focus from the politics in China to commercial news. The newspapers that emerged between 1911 and 1942 included Nanyang Siang Pao (est.1923, published by Singaporean business tycoon Tan Kah Kee) and Sin Chew Jit Poh (est. 1929, published by Singaporean, Aw Boon Haw). After the Malayan independence in 1957, the Chinese language newspapers and other forms of print media began to focus on the construction of a national culture and identity. Chinese language newspapers however, retained their "traditional roles" as the mouthpieces and representatives of defending the communal and cultural rights of the Chinese community. This shift in focus marks a huge development in the roles of Chinese language newspapers since the founding of Chinese language newspapers from the British colonial era (Mohd. Dhari, 1992). Chinese language newspapers henceforth focused on the preservation of Chinese culture through the news coverage and became one of the three main pillars of the Chinese society: Chinese education; Chinese language newspapers and Chinese guilds and associations. ${ }^{6}$ For example, Chinese language newspapers protect the rights of Chinese-based education by reporting on issues related to Chinese schools or by organising fund raising events for such schools. ${ }^{7}$ This form of reporting is in line with the role of Chinese-language newspapers as "public instruments" that cater for the intellectual, psychological, political and moral needs of all groups within the Malaysia Chinese community (Wong, 2001).

\section{CHINESE MIGRATION AND NATION BUILDING IN MALAYSIA}

Demographically, Malaysian society is divided according to ethnicity. The Malays and Bumiputeras (literally sons of the soil) comprise the largest ethnic group, followed by the Chinese, Indians and Others. The ethnic diversity with their competing claims, tensions and manifestations in various forms pose the main challenge to the political governance of the new nation-state even before independence (UNESCO, 1984: 109). Ethnic segregation is a form of social engineering that forced the different ethnic communities to live separately through 
the divide and rule policy. The actual purpose of the divide and rule policy was to hinder any great deal of interaction between the three main ethnic communities to reduce any possibility of a united nationalistic consensus leading towards a rebellion against the British colonialists. Chinese and Indian immigrants were brought to stimulate the growing interests in rubber and tin. The Malays were placed in the civil service, Chinese in the tin mines and Indians in the estates. This effectively placed different cultures within the same social or cultural space (Hefner, 2001: 4) but without overlapping ethnic interests (Banchoff, 2007: 4-5). As a result, a pluralistic society was created.

In 1850, Chinese migrants began to concentrate in tin mines located in the states of Perak, Selangor and Negeri Sembilan as coolies or managers. These Chinese migrants were conscious of their family systems, their homeland in China and ties with fellow Mainland Chinese or diasporic Chinese communities within Asia (Wang, 2000). According to Wang, this form of historical identity however, was under constant attack by a new and aggressive form of Chinese nationalism built upon Sun Yat Sen's concept of race and nation or minzhu (民族). Chinese immigrants in Malaya also propagated this form of China-centric sense of nationalism as a sense of Chinese nationalist identity began to emerge.

During the Malayan post-independence era, the dominant Chinese nationalist identity was forced to give way to a new localised national identity in the 1950s and 1960s. The 1950s also marked the cessation of Chinese migration to Malaya. In an independent Malaya, the local Chinese community, which consisted of immigrant and local born Chinese, were willing to desert their Chinese nationalist identity and replace it with a new Malayan national identity (Wang, 2000). At the same time this group of Chinese individuals developed a powerful sense of local ethno-communal identity. Wang explains this:

...the community leaders still retained some sense of their earlier historical identity as Chinese and also sought to have the cultural features of that identity officially recognised as an integral part of a composite Malayan national identity.

(Wang, 2000: 201)

The forceful Chinese communal identity developed for political purposes in Malaya could not be found anywhere else because no other communities were large enough to share power with the indigenous people to even a limited extent (Wang, 2000: 202). During the negotiation for independence led by first Prime Minister Tunku Abdul Rahman, the British had necessitated the formation of a multi-ethnic political alliance to administer the new nation. As a result, the Alliance Party that comprised the United Malays National Organization (UMNO), 
Malaysian Chinese Association (MCA) and Malaysian Indian Congress (MIC) was formed, with each party claiming to communally represent the Malays, Chinese and Indians respectively. As the nation building process began in postcolonial Malaya, state power was employed in the construction of a common national identity. National identity here assumes some commonly accepted criteria that make one national population distinct from another (Ma and Cartier, 2003: 53). The rise in ethnic tensions supposedly due to economic imbalance between the different ethnic groups eventually led to rising tensions that ended with a race riot on 13 May 1969 (Brown, 1996). This riot led to a state of emergency being declared and Parliament being suspended. As measures of restoring unity, a national ideology or Rukun Negara was formulated, alongside the introduction of New Economic Policy (NEP) in 1971, National Culture Policy (NCP) in 1970, National Education Policy, National Language Policy, formation of the Barisan Nasional (BN) unity government and creation of a Ministry for National Unity and Community Development (Kua, 2015).

In particular, the implementation of the NEP, which aimed at the redistribution of the wealth of the nation from foreign to local (mainly Bumiputera) ownership, has instead caused a "crippling polarization of Malaysian society and a costly brain drain" (Kua, 2015). Another state policy, which was deemed as favouring one ethnic community over the others, was the National Education Policy. The policy introduced in the 1960s was criticised by the leaders of the Malaysian Chinese community for forcing the Chinese schools to change the medium of teaching from Mandarin to Malay or English language in order to get the financial support from the government. As a result of this disparity, the Chinese language based schools then withdrew from the National Education System. Another policy deemed as lopsided is the NCP. Formulated in 1971, the NCP was solely based on the Malay culture and Islamic values and was eventually criticised by the Chinese community as a mono-ethnic policy that marginalised the Chinese culture. In the 1980s, a number of issues raised by the Malaysian Chinese community were related to the usage of Chinese-language in the vernacular schools and Chinese performing arts. For example, the banning of Chinese lion dance since the 1970s and requirement to obtain permits for lion dance performances during Chinese New Year celebration was another controversy surrounding the Chinese community in the 1980s. Another example is the controversy of the appointment of non-Mandarin trained administrators in Chinese national-type schools in the 1987. The examples above indicate how issues related to Chinese education and Chinese cultures, which are seen as pillars of the Malaysian Chinese community are constantly facing threats and are thus in need of being preserved and thus leads to the notion that nation building is constantly being contested in Malaysia.

Despite being an independent nation since 1957, the notion of nationhood remains heavily contested. In the 1960 s, the idea of nationhood was propagated 
through Lee Kuan Yew's concept of a "Malaysian Malaysia". This was followed by Mahathir Mohamad's "Bangsa Malaysia" in the 1990s and most recently; Najib Razak introduced his "1Malaysia". These contesting ideas of nationhood, coupled with the division between those constitutionally defined as Bumiputera, whilst leaving the rest to be termed as non-Bumiputeras, can be better understood through the definitions of an authority-defined social reality and everyday-defined social reality (Shamsul, 1996). In short, the former refers to the definition by the people in the power structure, namely the Barisan Nasional government while the latter refers to the definition based on the experiences of the people in their everyday life. Authority-defined social reality is also a Bumiputera-centric identity that locates Bumiputeras (note: Malay culture) as the "core" Malaysian national identity while recognising the cultural symbols of other ethnic communities. Three groups, namely the non-Bumiputera communities of the Chinese, which has been in existence in Malaysia for generations to continue seeking for their own sense of cultural identity (Wang, 2000) and two Bumiputera groups, i.e. the non-Muslim Bumiputera groups (native communities of Sabah and Sarawak) and the radical Islamic Bumiputera group have challenged this definition. As such, each community offers its own nation-of-intent with its own vision of what the Malaysian national identity should be. This causes debates about what constitutes the Malaysian national identity to continue until today.

As such, national identity and ethnic relations are issues that concern the State ever since the times of pre- and post-independence. Very often, the media, through different language newspapers, is seen as an important tool in helping narrow race, religion, culture and language differences by promoting harmonious ethnic relations and better understanding among ethnic communities (Chang, Faridah and Kuik, 2012). While it is inevitable that Sin Chew Daily as a Chinese language newspaper exists to preserve the Chinese culture, the newspaper is also expected to contribute to the development of nation building.

\section{RESEARCH METHODOLOGY AND ANALYSIS OF NEWS AGENDAS IN SIN CHEW DAILY}

In order to achieve a holistic data collection and analysis, this paper employs the mixed methods approach, and in particular the sequential explanatory design. In first phase of the data collection process, the sequential explanatory design allows the researcher to collect quantitative data through content analysis followed by collecting qualitative data through in-depth interview in the second phase. The rationale behind using sequential explanatory design is that the quantitative data and their subsequent analysis provide a general understanding of the research problem. Then, the qualitative data and their analysis refine and explain those 
statistical results by exploring respondents' views in greater depth. ${ }^{8}$ For this paper, the first phase of data collection is a content analysis of Sin Chew Daily and the second phase an in-depth interview with a media gatekeeper of Sin Chew Daily.

Using nonprobability purposive sampling, the research sample selected is Sin Chew Daily, as purposive sampling requires the selected sample to meet specific characteristics or qualities (Wimmer and Dominick, 2014). Sin Chew Daily fulfils the criteria, as the newspaper is the highest circulated Chinese language newspaper and the highest circulated newspaper across all languages in Malaysia. According to the Audit Bureau of Circulation Malaysia, between July to December 2012, the circulation of Sin Chew Daily stood at 386,693. ${ }^{9}$ In short, as the leading Chinese language newspaper in Malaysia, Sin Chew Daily is read by Chinese-educated Malaysian, and with more than 1.18 million Malaysians reading Sin Chew Daily, the newspaper becomes a highly influential Chinese language newspaper in Malaysia. ${ }^{10}$

It is also important to note that the content of Sin Chew Daily published in West or Peninsular Malaysia is different with that from East Malaysia, namely Sabah and Sarawak. The West Malaysian version mainly focuses on political, social, economic and cultural news, while the East Malaysian version reports on news about politics, economic, society and culture of the two states. For the purpose of this study, only Sin Chew Daily published in West Malaysia is examined due to the different content as well degrees of representation.

Sin Chew Daily is also published in a broadsheet format. The West Malaysian version is divided into the National Edition (mostly national news) and Regional Edition (mostly local news), and other supplements for economics sports, entertainment and lifestyle news. ${ }^{11}$ For this paper, only news from the National Edition, which is published on an average of thirty-five pages per day, was analysed using content analysis. The research period of 1 August to 31 October 2012 is chosen because the Malaysia 13th General Election (GE13) was expected to be held during these period. During and before the general elections, issues related to Chinese education, cultural rights, national identity and ethnic relations were highlighted in Chinese language newspapers. It is therefore crucial to examine how Sin Chew Daily reported Chinese cultural preservation and nation building during this particular period.

This paper would also identify the unit of analysis and explained each of the unit and its category under the operational definition (see Operational Definition under Table 6[a] in Appendices). In order to collect data and to enable a more systematic coding process, a coding descriptor and coding sheet were created using Microsoft Excel 2013. The coding descriptor provides an explanation of each code and category used, while the coding sheet that consists of the date, types of news, headlines, page number, news source, news slant and picture used was designed to assess the news item identified in Sin Chew Daily. Both the coding descriptor and 
coding sheet were modified from Chang, Faridah and Kuik (2012) and expanded based on the needs and nature of this paper. As there is only one coder in this study, thus, no inter-coder reliability test was conducted. The data of the content analysis was also tabulated and presented using frequency and percentage.

During the research period, a total of 1,213 news reports related to the theme of (1) cultural rights, (2) Chinese education, (3) religious rights, (4) ethnic relations, and (5) national identity were published in Sin Chew Daily. The news agenda of Chinese cultural preservation was measured based on news of cultural rights, news of Chinese education and news of religious rights; while the news agenda for nation building was measured based on news of ethnic relations and news of national identity.

News of cultural rights was divided into six categories. They included the following news: (1) local Chinese guilds and associations (CGAs), (2) local Chinese festivals, (3) local Chinese cultural activities, (4) news related to the Chinese language, (5) Chinese literature, and (6) Chinese literature workshops or competitions. Chinese educational issues were then divided into two categories: news of local Chinese schools, and news of local Chinese educational issues. News of religious rights refers to news of local Chinese temples, and news of local Chinese religious activities involving (but not limited to) Taoists, Buddhists, Christians or Muslims. News of ethnic relationship issues refers to news about local ethnic relations, and news that promote good ethnic relations. Lastly, news of national identity issues refers to all news related to national identity issues in Malaysia (see Table 6[a] in Appendices).

Each of the above mentioned themes (cultural rights, Chinese education, religious rights, ethnic relations, and national identity) was then analysed based on page number, source of news, news slant, and picture used. The page number was divided into four categories: front page, page two and page three, rest of the news section, and front page continues to other pages. News sources was divided into ten categories: government (BN and PR), political parties (government and opposition), Chinese ethnic NGOs (non-governmental organisations), other ethnic based NGOs, non-ethnic based NGOs, religious groups (Chinese and non-Chinese), editorials, readers viewpoints/opinions, others, and unclear news sources. News slant was divided into neutral, pro issues, and against issues; and pictures used were divided into colour, and non-colour (see Table 6[a] in Appendices).

According to the results of the content analysis, during the research period, Sin Chew Daily mostly publishes news related to issues of Chinese language education $(56.0 \%)$. This is followed by news of cultural rights $(37.0 \%)$, religious rights $(4.0 \%)$, ethnic relations $(2.4 \%)$ and national identity (0.6\%) (see Table 1 [a] in Appendices).

As mentioned above, in-depth interview was conducted as the second phase of data collection to provide further explanation and elaboration of the 
findings in content analysis, as well as to help to answer the research questions. Purposive sampling method was used in selecting the respondents of the in-depth interview and the purposive sample or respondent must be able to express his/ her opinions on the news representation of Sin Chew Daily in Chinese cultural preservation and nation building.

For the in-depth interview, the respondent is the main gatekeeper of Sin Chew Daily. The interview was conducted on 8 November 2013 at the headquarters of Sin Chew Daily, Petaling Jaya, Selangor. Data collected is to answer the research questions related to Chinese cultural preservation and nation building in the context of ethnic relations and national identity in Sin Chew Daily. After the interviews, the data was transcribed based on the audio recording as well as the written records. The data is then analysed based on the significance of the answers given by the respondent. Lastly, the interview data was synthesised and grouped under a theme which was identified based on the data collected. This is then discussed in the different themes below.

\section{NEWS OF CHINESE CULTURAL PRESERVATION IN SIN CHEW DAILY}

\section{The News Agenda of Sin Chew Daily}

According to the media gatekeeper of Sin Chew Daily, the newspaper focuses on news related to Chinese politics, Chinese education, Chinese Guilds and Associations (CGAs), as well as the Chinese media. Out of these, Chinese education is one of the most important news sources for the newspaper. This is shown in the following statements:

华社四大支柱：华人政党、华教、华人社团跟华文媒体，四位是 一体的，缺一不可。所以我们的方针就是涵盖着四方面。在华教 方面，星洲日报是特别关注的。我们1988年被关闭的时候也是因 为华教问题……不管是董教总谈华教问题，独中也好，华小师资 问题、华小搬迁、增建都好，这些都是我们着重的……复刊后我 们就很着重华社的政、经、文、教问题, 就不单单是华教, 甚至 经济，我们也非常着重。(星洲日报新闻把关人)

Translation:

The four pillars of the Malaysian Chinese community are: Chinese political parties, Chinese education, Chinese guilds and associations and Chinese media. These four are indispensable and inseparable. Therefore, our editorial policy requires us to cover these four areas. In fact, $\mathrm{Sin}$ 
Chew Daily focuses very much on Chinese education issues. In 1988, our printing permit was suspended because of Chinese education issues...we covered Jiaozong's statement about Chinese education issues, Chinese independent schools, shortage of teachers in Chinese primary schools, the relocation of the Chinese schools or expansion of Chinese school buildings... after the suspension of the printing permit was removed, we started to focus on issues related to politics, socio-economy, culture and education that are related to the Chinese community. We also focus on the economic news.

(The media gatekeeper of Sin Chew Daily)

The gatekeeper in Sin Chew Daily asserts that the newspaper does not limit itself when it comes to front-page news. Social news can be the front-page story if it brings much impact to society as compared to others. Below are the statements by the media gatekeeper:

我们在版位分配方面是没有自我设限的。我们可以用社会新闻当 封面, 如果那个社会新闻关系比较深远的。星洲/ 我们还是严肃 的报纸。虽然我们登很多社会新闻，基本上我们还是严肃的报 纸。我们有一个底线, 一些东西我们是不登的。比如说比较残酷 的社会新闻照片，不过有时疏忽，还是不小心走出来。（星洲日报 新闻把关人)

Translation:

We do not practice self-censorship when allocation news items to its pages. We could use social news for the front page if the news items provide much impact to society... Sin Chew - we remain a serious newspaper. While we mostly print social news, we fundamentally remain a serious newspaper. We set a limit. There are things that we do not publish, pictures of social news that look gruesome for example, but we might at times overlook this and publish it by accident.

(The media gatekeeper of Sin Chew Daily)

\section{News of Chinese Education}

The content analysis of Sin Chew Daily news shows how Chinese language newspapers in Southeast Asia, particular Malaysia, function as an important tool to extend and preserve the Chinese culture in the overseas Chinese diaspora world. As the largest circulated Chinese language newspaper in Malaysia, much space in Sin Chew Daily is allocated for news about Chinese education (55.8\%) and cultural 
rights (37.0\%), while news of local Chinese education (50.2\%) and local Chinese schools $(49.8 \%)$ are equally represented. News reports by Sin Chew Daily during the research period include the status of Sekolah Menengah Chong Hwa Kuantan, Chinese independent schools and education fund allocations to all types of Chinese schools, the need to recognise the Unified Examination Certificate (UEC) as an official national university entry examination, shortage of Chinese language schools and Chinese language school teachers, relocation of Chinese schools, the controversial Malaysia Education Blueprint 2013-2025, rallies organised by United Chinese School Committees Associations of Malaysia (dongzong 董总) on 26 September and 25 November, and the upgrade of Tunku Abdul Rahman (TAR) Colleges to university college status.

For a thorough analysis, news related to Chinese education as well as the page number, source of news, news slant and picture used were also examined. From August to October 2012, a total of 508 most coloured pictures were used for the news of Chinese educational issues in Sin Chew Daily (see Table 5[a] in Appendices). Based on an average of 34 pages publication a day, the majority of news about Chinese education were published in the rest of the news section $(82 \%)$, some in page two and page three (13\%) and a few in the front page (1\%) of the newspaper (see Table $2[\mathrm{~b}]$ in Appendices). The findings indicate that the main sources of news about Chinese education are largely from Chinese ethnic NGOs such as Lim Lian Geok Cultural \& Development Centre, the Board of Directors of the Chinese schools, National Union of Heads of Schools, United Chinese School Committees Associations of Malaysia and its branches in each state of Malaysia (dongzong 董总 or dong lianhui 董联会), Chinese guilds and associations, The Federation of Chinese Associations Malaysia and its branches in each state of Malaysia (huazong 华总 or huatang 华堂), The United Chinese School Association of Malaysia (jiaozong 教总) and The Malaysian Chinese Schools' Alumni Association (xiaoyou lianzong 校友联总) (see Table 3[b] in Appendices).

Another source of news of Chinese educational issues in Sin Chew Daily was the articles related to Chinese education that published in the "Opinion Corner" in Sin Chew Daily. "Opinion Corner" is where Sin Chew Daily publishes the readers' viewpoints or opinions from columnists, which also include the articles by the political writers and reporters from Sin Chew Daily. Besides that, the parties of the Barisan Nasional (BN) ruling coalition were also an important source on Chinese educational issues, in comparison to the opposition Pakatan Rakyat (PR) coalition parties (see Table 3[b] in Appendices). On average, about $70 \%$ of news about Chinese educational issues was reported as neutral and only a quarter was reported as supporting (pro) the issues (see Table $4[\mathrm{~b}]$ in Appendices).

The main concern of Mandarin speaking Malaysian Chinese is Chinese language education. This fact is reiterated by Sin Chew Daily's gatekeeper who 
mentioned during the in-depth interview that Chinese education issues that greatly concern the Malaysian Chinese community are issues related to national-type Chinese primary and secondary schools, issues of Chinese-independent schools, issues of three Chinese community-run colleges: Han Chiang College, New Era College and Southern College; and the MCA-run TAR Colleges and University of Tunku Abdul Rahman (UTAR). Below is the example of in-depth interview data:

\begin{abstract}
在华教方面，星洲日报是特别关注的。我们1988年被关闭的时候 也是因为华教问题......不管是董教总谈华教问题，独中也好，华 小师资问题、华小搬迁、增建都好，这些都是我们着重的.....复 刊后我们就很着重华社的政、经、文、教问题，就不单单是华 教, 甚至经济, 我们也非常着重。(星洲日报新闻把关人)
\end{abstract}

Translation:

Sin Chew Daily focuses very much on issues of Chinese education. In 1988 , our printing permit was suspended because of Chinese education issues...we covered Jiaozong's statement about the Chinese education issues, Chinese independent schools, shortage of teachers in Chinese primary schools, relocation of Chinese schools or expansion of Chinese school buildings....after the suspension of the printing permit was lifted, we started to focus on issues related to politics, socio-economics, culture and education that are related to the Chinese community. We also focus on the economic news.

(The media gatekeeper of Sin Chew Daily)

Chinese language education is seen as a cornerstone of the Malaysian Chinese community because Chinese language based schools/education is historically seen as a way of extending and preserving the Chinese culture and as a symbol of the Malaysian Chinese communal identity. The struggle for Chinese vernacular schools, and in particular, Chinese independent type schools to be recognised as part of the national education system by the Chinese educationists has been on-going since the pre-independence era and supported by Chinese guilds and associations and Chinese language media.

Since the time of independence, the government has however allowed the usage of vernacular languages that include Mandarin and Tamil as teaching mediums in primary schools. These types of schools are categorised as the nationaltype of Chinese or Tamil primary schools. There are in total 1,295 national-type Chinese primary schools throughout Malaysia that follow a common national curriculum but managed by independent Chinese school boards and committees. ${ }^{12}$ 
Over the past decade, a decrease in student numbers has forced certain nationaltype Chinese primary schools to move to areas with a denser Chinese population.

The closure of Chinese vernacular schools is often deemed as a sensitive issue to many Malaysian Chinese. For example, in 2014, a provocative statement on shutting down Chinese and Tamil vernacular schools by Idris Jusoh, then Deputy Education Minister II received fierce criticisms from the then MCA Youth Chief, Chong Sin Woon (Sinchew-i, 2014). Unlike the government funded nationaltype primary schools that use the Malay language as their medium of instruction, national-type Chinese vernacular primary schools only receive partial aid from the Federal Government. In addition to these Chinese vernacular primary schools, there are in existence 78 national-type Chinese vernacular secondary schools and 60 Chinese independent type schools in Malaysia. In 1962, national-type Chinese vernacular secondary schools were converted from Chinese independent schools to national-type secondary schools, which are not fully funded by the government. Chinese independent type schools remain fully independent after 1962 and are fully funded by the Malaysian Chinese community and uses different syllabi as compared to the national-type secondary schools (Palanca, 2002). The vision of the Mandarin/Chinese speaking Malaysian Chinese community is to have a comprehensive system of Chinese-medium education spanning from the primary to tertiary level.

\section{News of Chinese Culture and Religious Rights}

Activities related to the preservation of Chinese culture are also often featured in the news coverage of Sin Chew Daily. As the Malaysian Chinese community still holds on to their intrinsic ethnic cultural identity and practices, the usage of Chinese language, namely Mandarin and Chinese literature continue being used alongside the various Chinese cultural activities and festivals continuously organised by the Chinese Guilds and Associations (CGAs). Major emphasis is given to the news of local Chinese guilds and associations (70.3\%) followed by news of local Chinese cultural activities (13.2\%). The other news is related to Chinese literature (7.1\%), Chinese language (4.2\%), local Chinese festivals (2.7\%) and of Chinese literature workshops or competitions (2.5\%) (see Table 1[b] in Appendices).

Malaysian CGAs play the role of social and welfare organisation for the Chinese community by expressing the demands of the Chinese community on matters of politics, economy, culture and education. CGAs are divided into dialect organisations (tongxiang huiguan 同乡会馆), clan affinities associations (zongqin xiangtuan 宗亲会馆), Chinese trade and guilds organisations (shanghui 商会) or industry organisations and other Chinese associations. Most of the news published during the research period are either related to the activities organised by CGAs or leaders comments about current affairs that affect the interests of their members and 
Chinese community such as the bird nest export controversy, implementation of minimum wage and proposal to relocate Chinese cemeteries in Pengerang, Johor, and the annual assembly of the Federation of Chinese Associations Malaysia's (huazong 华总). ${ }^{13}$

The majority of news about cultural rights is published in the rest of the news section of the newspaper along with news of Chinese educational issues (see Table 2[a] in Appendices). The primary sources of the news are from the CGAs and Chinese NGOs such as Lim Lian Geok Cultural \& Development Centre, huazong or hua tang, jiaozong, dongzong or dong lianhui, the BN government and "Opinion Corner" (see Table 3[a] in Appendices). The majority of news about cultural rights is reported as neutral and a few as pro-cultural rights (see Table 4[a] in Appendices). From a total of 472 pictures used, 76\% of coloured pictures are published together with the news (see Table 5[a] in Appendices).

The importance of news about education issues and cultural rights in Sin Chew Daily is confirmed by its gatekeeper who stated that the newspaper maintains a favourable relationship with numerous CGAs, educational bodies and Chinese chambers, such as the Federation of Chinese Associations Malaysia (huazong), The Federation of Seven clans, United Chinese School Committees Associations of Malaysia (dongzong), The United Chinese School Association of Malaysia (Jiaozong), Lim Lian Geok Cultural \& Development Centre, Kuala Lumpur-Selangor Chinese Assembly Hall, The Chinese Chamber of Commerce and Industry of Kuala Lumpur and Selangor, The Associated Chinese Chambers of Commerce and Industry of Malaysia, as well as Chinese NGOs such as Coalition of Plan of Action for Malaysia. These institutions are in fact frequently mentioned in the newspaper's reports. According to the gatekeeper, Sin Chew Daily does not only report about Chinese cultural activities but also plays the role as the organiser or co-organiser of Chinese cultural events. The Flora Trail Chinese Literature Award founded by Sin Chew Daily and the establishment of the Culture and Education Department in 1992 are two main indicators about the importance of Chinese culture preservation agenda in the newspaper.

On the other hand, most of the news pertaining to religious rights are primarily related to the news about Buddhism and Taoism, while little news concern the Chinese Muslims in Malaysia. The majority of news about religious rights is attributed to news of local Chinese religious activities (83\%) and local Chinese temples (17\%) (see Table 1[d] in Appendices). A total of $98 \%$ of news about religious rights is found in the rest of the news section and only $2 \%$ is found in pages two and three (see Table 2[c] in Appendices). Almost all the news sources about religious rights are from Chinese religious groups (see Table 3[c] in Appendices). There are two commentaries related to religious rights in the "Opinion Corner" while one is depicted in the Editorial column of Sin Chew Daily. Most of the news of religious rights is reported as neutral (see Table $4[\mathrm{c}]$ in Appendices). A total of 
44 pictures are published with $86 \%$ being coloured pictures. The above analysis of Chinese education issues, cultural and religious rights indicates that Chinese cultural preservation is the most important news agenda of Sin Chew Daily.

\section{NATION BUILDING NEWS: LEAST REPORTED BUT NEVER IGNORED}

In comparison to news categorised as Chinese cultural preservation, Sin Chew Daily least covers news categorised under the nation-building category. This is empirically supported by the news categorised as news that promote good ethnic relations and news related to ethnic relations. The research results show that the news coverage of the two categories of Chinese cultural preservation and nation building is less than $3 \%$ of the total 1,213 news found during the research period (see Table 1[a] in Appendices).

From these two categories, the majority of news promote good ethnic relations (69\%), while the rest are related to local ethnic relations (31\%) (see Table $1[\mathrm{e}]$ in Appendices). Only 26 pictures are published and $73 \%$ of them coloured (see Table 5[a] in Appendices). About $90 \%$ of news published in the rest of the news section and $10 \%$ are published in pages two and three (see Table 2[d] in Appendices). Half of the news reports are supportive of better ethnic relations in Malaysia and half are reported as neutral (see Table 4[d] in Appendices). The main sources of the news are from the $\mathrm{BN}$ government, followed by $\mathrm{BN}$ ruling parties and PR parties (see Table 3[d] in Appendices).

Other than the comments of leaders from BN and PR, the Sin Chew Daily gatekeeper stated that, Sin Chew Daily also takes the lead to initiate some feature stories that promote good ethnic relations. One such example is the coverage of PMR and SPM examinations. The focus is not only on Chinese students who achieved good results but also on students from other ethnic groups. The news report also included students with disabilities who performed well in these national examinations. The gatekeeper also asserted that Sin Chew Daily published a lot more news on other ethnic groups as compared to the Malay language newspapers in this country. An example of such publications is a series of reports about the friendship between the Chinese community and other ethnic groups in Malaysia. One of the stories described how a Malay individual helped his Chinese friend who was in need of help. Other than that, Sin Chew Daily also highlighted issues of poor Malay families. These efforts, according to the gatekeeper, are to reduce the growing ethnic polarisation between the different ethnic communities in the country.

The gatekeeper also stated that Sin Chew Daily attempts to play down racist issues by only reporting about an event without sensationalising them. The newspaper however, allows its columnists to criticise those who sensationalised 
ethnic issues such as the 13 May race riots. In reporting crime news, the newspaper avoids highlighting the ethnicity of the alleged perpetrator because Sin Chew Daily believes that crime can be committed by anyone regardless of ethnicity. For example, Sin Chew Daily did not state the ethnicity of a taxi driver who raped his female passenger. The newspaper however received a public backlash, as its readers wanted the newspaper to disclose the ethnicity of the driver in its news report so that the public could take precautionary steps in the future. Since then, Sin Chew Daily will examine the impact of its readers and society before deciding to disclose the ethnicity of the alleged offender(s) in crime news reporting.

In terms of national identity issues, the Sin Chew Daily's gatekeeper stated that that nothing much can be done by the media or newspapers should discriminatory policies and the provoking of racial sentiments continue to be propagated by the ruling government. The gatekeeper also believed that the government should spearhead nation building efforts. To do so, the government needs to first remove the column indicating ethnic identity in all application forms of government-linked agencies. The second problem, in the opinion of the gatekeeper, is the usage of bumiputera and non-bumiputera terms that seem to continuously segregate Malaysians. Owing to these issues, Sin Chew Daily has little choice but to highlight the views of the Malaysian Chinese community by expressing their unsatisfactory feelings towards such unequal policies.

Although the findings show that Sin Chew Daily published little news of nation building during the three-month research period, the gatekeeper asserted that nation building remains an agenda that is never ignored by Sin Chew Daily, especially issues related to ethnic relations.

\section{DISCUSSION: SIN CHEW DAILY, SOCIETY, THE MARKET AND STATE}

An analysis of the data above, shows that Chinese cultural preservation through news reporting of Chinese education, Chinese culture and religious rights remain the priority and precedence for Sin Chew Daily as compared to the agenda of nation building. In society, both the news agendas of Chinese cultural preservation and nation building in Sin Chew Daily evidently show that Sin Chew Daily, as a Chinese communal press in multi-ethnic society in Malaysia, does in fact respond to the needs of society in which it exists, i.e. the Chinese society in particular and all Malaysians in general. In addition, Sin Chew Daily also responds to government efforts in building a Malaysian nation after Merdeka or Independence, especially on issues of ethnic relations and national identity. Such efforts are also in line with the statement made by the interviewed Sin Chew Daily gatekeeper regarding news agenda of Sin Chew Daily as discussed above. 
The above findings also prove that Sin Chew Daily holds strong to its fundamental responsibility of defending the rights of the Chinese speaking community in terms of education, culture and religion. This is most evident when issues of Chinese education are criticised and debated among the Chinese speaking community and by Chinese education organisations dongzong, jiaozong, dongjiao zong, donglian hui, xiaoyou lianzong and Chinese Guilds and Associations (CGA) huazong, huatang and xue huatang (雪华堂). The status of Chinese independent high schools and national-type Chinese primary school, for example, and issues of monetary allocation to all Chinese schools (including Chinese independent schools, national-type primary and secondary Chinese schools,) remain unresolved since Merdeka. While this shows a cordial relationship between Sin Chew Daily and the CGAs, this also proves that its subscribers contribute to the readership and circulation of the newspaper.

Sin Chew Daily's readership and circulation remain highly dependent on the Chinese in particular its 386,693 Chinese speaking subscribers. Besides advertising revenue, market forces remain key feature to the survival of Sin Chew Daily as it is also highly dependent on readership and circulation through the sales of the printed copies. The monolingual characteristics of Sin Chew Daily however limit its readership to only those literate in Mandarin. In terms of market share, Sin Chew Daily also competes with online newspapers besides competing with other Chinese language newspapers in West Malaysia such as Oriental Daily News (东方日报), Kwong Wah Yit Poh (光华日报), Guang Ming Daily (光明日 报), Nanyang Siang Pau (南洋商报), and China Press (中国报). ${ }^{14}$ According to Statista (n.d.), advertisers have reduced spending in newspapers and, diverted this spending for online advertising. In Malaysia, advertising expenditure for online media shows a spike of more than $173 \%$ in 2013 as compared to 2008. In short, Sin Chew Daily remains highly dependent on the support of its Chinese-educated readers for survival.

Besides responding to the Chinese society and the market, Sin Chew Daily also responds to the State. The portrayal of Chinese cultural preservation news agenda by Sin Chew Daily indirectly contests the Malay/Islam-centric nationbuilding agenda of the UMNO-led government (Shamsul, 1996), and in particular the issue of "Malay" national identity versus "Chinese" cultural identity. To many Malaysian Chinese, especially Chinese-educated, the Chinese language, culture, family system, and ties with Mainland China are seen as what constitute Chineseness (Purcell, 1967; Leong, 1976; Carstens, 1988; Shamsul, 1999). The disparities in defining what constitutes nation building and national identity sums up the tension between the State and minority Chinese ethnic community occasionally emphasised by Sin Chew Daily.

Sin Chew Daily, the minority ethnic press remains vigilant in its news publishing as it is constantly regulated by the Printing Presses and Publication 
Act (PPPA) (Amendment 2012), Sedition Act, Official Secrets Act and Internal Security Act (repealed and replaced by Security Offenses [Special Measures] Act SOSMA 2012). Like every other printed press in Malaysia, Sin Chew Daily are constrained by such laws that stifle media scrutiny of the ruling government and public debate about social and political issues (Mustafa K. Anuar, 2014: 87).

The above discussion highlights how news about Chinese cultural preservation and nation building by Sin Chew Daily exemplifies the newspaper's responses to the society, state and market of Malaysia. Despite reporting on such issues, the neutral position adopted by Sin Chew Daily in its news reporting indicates its cautious approach about such issues. As such, other than "reporting news", Sin Chew Daily does not provide a proper platform to debate such issues.

\section{CONCLUSION}

Chinese educational issues, cultural rights and religious rights are the main news agendas of Sin Chew Daily. This is supported by the quantity of the news reported, pictures used and specific pages where the news is published. Statements made by its gatekeepers affirm this fact. In terms of news quantity, not much news coverage on issues of nation building are found but in terms of news angles and treatment, Sin Chew Daily goes beyond ethnic boundaries by actively reporting about nonChinese news but fails to play a more vital role on issues of national identity. This is because state policies have been historically divisive along ethnic lines, which ultimately hinder the creation of a one proper national identity, embraced by all Malaysians.

As Malaysia continues to be dominantly governed by the United Malays National Organization (UMNO)-led government, the emphasis on Malay-centric state policies continues to persist. This has contributed to a mono-ethnic affirmative approach towards nation building that continue to be contested by other ethnic communities in Malaysia. This causes Malaysia to remain a "nationless" state still in search of its elusive "united Malaysia nation" and national identity, as various notions of nations-of-intent are still entertained (Shamsul, 1996: 481). The failure to recognise and highlight the fact that dissenting voices are present and heard, within and beyond the government in Malaysia causes a healthy competing discourse on "nation-of-intent" and "national identity" to continue taking place amongst Malaysians, particularly the Malays. Nation building therefore becomes a challenging task to the ruling government, nation and media. As the Malaysian Chinese remains the second largest ethnic community, it is important for the Chinese language media to create a platform for intercultural and interethnic debates on the issues related to nation building and national identity. 
It is encouraging to note that Sin Chew Daily continues to successfully play its role in representing the news of Chinese educational issues, cultural and religious rights, national identity issues and news that promote good interethnic relations. Nevertheless, more efforts are needed for the newspaper to communicate clearly the nation-of-intent of the Malaysian Chinese community to the ruling government; as well as to enhance its role in establishing a constructive debate platform for the Malaysian civil society to decide on its nation-building "formula" that is accepted by all citizens.

\section{ACKNOWLEDGEMENTS}

The SEGi University Research Fund, SEGiIRF/2014-22/SOCS-2/37, funded this study. The first draft of this paper was written for the Second Biennial International Conference on Malaysian Chinese Studies, 2014 held in Kuala Lumpur, 20-21 June 2014. In writing this paper, we have benefited from comments from Dr Mahyuddin Ahmad, Senior Lecturer, School of Communication, Universiti Sains Malaysia and Mr Ng Siang Teik, Lecturer, SEGi University.

\section{NOTES}

1. This phrase is commonly mentioned by Tiong Hiew King when criticised by the Malaysian civil society about the merger and acquisition of Sin Chew Daily with the other Chinese newspaper group, namely the Nanyang Press Holdings Berhad and the Hong Kong-based Ming Pao Enterprise Corporation Limited in April 2008.

2. See the statement of the then Editor-In-Chief of Sin Chew Media Corporation, Siew Nyoke Chow on the First Forum of Global Chinese Language Media on 2001 in China (http://www.fcm.chinanews.com.cn/2001-09-18/2/268.html; accessed 18 July 2010).

3. According to the latest statistics by the Audit Bureau of Circulation, the circulation of Sin Chew Daily in July-December 2015 was 340,584. The circulation during the research period, i.e. July-December 2012 was 404, 478.

4. This is a common notion used by Tiong Hiew King and his pressman when they were criticised by the Malaysian civil society on the merger and acquisition (M\&A) of Chinese dailies in 2008. In the M\&A exercise, Sin Chew Daily, China Press, Nanyang Siang Pao and Guang Ming Daily were merged under a new media entity, namely the Media Chinese International Limited.

5. For further reading see Chinese Monthly Magazine (察世俗每月统计传). (n.d.). Retrieved from http://digibase.ssic.nccu.edu.tw/?m=2302\&wsn=0383

6. See "The three pillars of the Chinese Community" in http://www.mca.org.my/2/ Content/SinglePage?_param1=27-032018-85591-03-201827\&_param2=TS accessed 4 April 2012. 
7. Examples of such events include the Top Ten Charity Campaign organised by Nanyang Siang Pau, China Press and sponsored by Carlsberg Malaysia since 1987.

8. Further reading, see Chapter 3: Choosing a Mixed Methods Design. Retrieved from https://us.sagepub.com/sites/default/files/upm-binaries/35066_Chapter3.pdf

9. For further information, see http://abcm.org.my/wp-content/reports/2012/ABCCirculation-Figures-Pen-Mal-Price-Band-Jul2012toDec2012.pdf

10. For further information, see Media Chinese International Limited official website. Retrieved from http://www.mediachinesegroup.com $/ \mathrm{htm} /$ content. cfm?channel=biz\&path=biz 05a\&lang $=\mathrm{E}$

11. Sin Chew Daily published a total of 11 regional editions in both East and West Malaysia to cater to the needs of the local people on the local news in different regions such as the northern region (Perlis, Kedah and Pulau Pinang), the Klangvalley (Selangor and Kuala Lumpur), the southern region (Johor), Melaka and Negeri Sembilan, Sabah and Sarawak (3 regional editions are published in Sarawak). For further information, see http://epaper.sinchew.my/sinchewepaper/webapp/.

12. See the report released by The United Chinese School Teachers' Association of Malaysia in 2015.

13. China banned the imports of bird's nests from Malaysia in July 2011 due to nitrite contamination.

14. In April 2008, Media Chinese International Limited has re-arranged their market strategy by audience segmentation in order to reduce the competition among the four newspapers owned by them after the merger and acquisition exercise. Sin Chew Daily mainly focuses on major issues and events in and outside the country; Guang Ming Daily serves readers in the northern states of Pulau Pinang, Kedah, Perlis and Perak states, as a regional newspaper. China Press mainly reports about crime and disaster news while Nanyang Siang Pau focuses on economic news reporting. 
Ng Miew Luan \& Lee Yuen Beng

\section{APPENDICES}

\section{Types of News}

Table 1(a): Total number of different type of news

\begin{tabular}{lcccccccc}
\hline Month & \multicolumn{2}{c}{ Aug'12 } & \multicolumn{2}{c}{ Sept'12 } & \multicolumn{2}{c}{ Oct'12 } & \multicolumn{2}{c}{ Total frequency } \\
\hline Theme & F & \% & F & \% & F & \% & F & \% \\
\hline Cultural rights & 171 & 38 & 143 & 32 & 134 & 30 & 448 & 37.0 \\
Chinese education & 222 & 33 & 245 & 36 & 210 & 31 & 677 & 56.0 \\
Religion rights & 14 & 27 & 12 & 23 & 26 & 50 & 52 & 4.0 \\
Ethnic relations & 13 & 45 & 14 & 48 & 2 & 7 & 29 & 2.4 \\
National identity & 4 & 57 & 1 & 14 & 2 & 29 & 7 & 0.6 \\
\hline Total & 424 & & 415 & & 374 & & 1,213 & 100.0 \\
\hline
\end{tabular}

Note: $\mathrm{F}=$ Frequency

Table 1(b): Cultural rights

\begin{tabular}{|c|c|c|c|c|c|c|c|c|}
\hline \multirow{2}{*}{$\begin{array}{l}\text { Month } \\
\text { Categories }\end{array}$} & \multicolumn{2}{|c|}{ Aug'12 } & \multicolumn{2}{|c|}{ Sept'12 } & \multicolumn{2}{|c|}{ Oct'12 } & \multicolumn{2}{|c|}{ Total frequency } \\
\hline & $\mathbf{F}$ & $\%$ & $\mathbf{F}$ & $\%$ & $\mathbf{F}$ & $\%$ & $\mathbf{F}$ & $\%$ \\
\hline $\begin{array}{l}\text { News of local Chinese guilds } \\
\text { and associations }\end{array}$ & 109 & 35 & 105 & 33 & 101 & 32 & 315 & 70.3 \\
\hline News of local Chinese festivals & 1 & 8 & 8 & 67 & 3 & 25 & 12 & 2.7 \\
\hline $\begin{array}{l}\text { News of local Chinese cultural } \\
\text { activities }\end{array}$ & 29 & 49 & 19 & 32 & 11 & 19 & 59 & 13.2 \\
\hline $\begin{array}{l}\text { News related to Chinese } \\
\text { language }\end{array}$ & 8 & 42 & 3 & 16 & 8 & 42 & 19 & 4.2 \\
\hline $\begin{array}{l}\text { News related to Chinese } \\
\text { literature }\end{array}$ & 17 & 53 & 8 & 25 & 7 & 22 & 32 & 7.1 \\
\hline $\begin{array}{l}\text { News of Chinese literature } \\
\text { workshop or competition }\end{array}$ & 7 & 64 & 0 & 0 & 4 & 36 & 11 & 2.5 \\
\hline Total & 171 & & 143 & & 134 & & 448 & 100.0 \\
\hline
\end{tabular}


Table 1(c): Chinese educational issues

\begin{tabular}{lcccccccc}
\hline Month & \multicolumn{2}{c}{ Aug'12 } & \multicolumn{2}{c}{ Sept'12 } & \multicolumn{2}{c}{ Oct'12 } & \multicolumn{2}{c}{$\begin{array}{c}\text { Total } \\
\text { frequency }\end{array}$} \\
\hline Categories & F & $\mathbf{\%}$ & F & \% & F & \% & F & \% \\
\hline $\begin{array}{l}\text { News of local Chinese schools } \\
\text { News of local Chinese educational }\end{array}$ & 55 & 50 & 81 & 24 & 89 & 26 & 337 & 49.8 \\
$\begin{array}{l}\text { issue } \\
\text { Total }\end{array}$ & 222 & & 245 & & 210 & & 677 & 100.0 \\
\hline
\end{tabular}

Note: $\mathrm{F}=$ Frequency

Table 1(d): Religious rights

\begin{tabular}{|c|c|c|c|c|c|c|c|c|}
\hline \multirow{2}{*}{$\begin{array}{l}\text { Month } \\
\text { Categories }\end{array}$} & \multicolumn{2}{|c|}{ Aug'12 } & \multicolumn{2}{|c|}{ Sept'12 } & \multicolumn{2}{|c|}{ Oct'12 } & \multicolumn{2}{|c|}{$\begin{array}{c}\text { Total } \\
\text { frequency }\end{array}$} \\
\hline & $\mathbf{F}$ & $\%$ & $\mathbf{F}$ & $\%$ & $\mathbf{F}$ & $\%$ & $\mathbf{F}$ & $\%$ \\
\hline News of local Chinese temples & 5 & 56 & 1 & 11 & 3 & 33 & 9 & 17.0 \\
\hline $\begin{array}{l}\text { News of local Chinese } \\
\text { religious activities (Taoist, } \\
\text { Buddhist, Christian, Muslim } \\
\text { etc.) }\end{array}$ & 9 & 21 & 11 & 26 & 23 & 53 & 43 & 83.0 \\
\hline Total & 14 & & 12 & & 26 & & 52 & 100.0 \\
\hline
\end{tabular}

Note: $\mathrm{F}=$ Frequency

Table 1(e): Ethnic relations issues

\begin{tabular}{lcccccccc}
\hline Month & \multicolumn{2}{c}{ Aug'12 } & \multicolumn{2}{c}{ Sept'12 } & \multicolumn{2}{c}{ Oct'12 } & \multicolumn{2}{c}{ Total frequency } \\
\hline Categories & F & $\mathbf{\%}$ & F & \% & F & \% & F & \% \\
\hline $\begin{array}{l}\text { News related to local ethnic } \\
\text { relation issue }\end{array}$ & 1 & 11 & 6 & 67 & 2 & 22 & 9 & 31.0 \\
$\begin{array}{l}\text { News that promoted good } \\
\text { ethnic relation }\end{array}$ & 12 & 60 & 8 & 40 & 0 & 0 & 20 & 69.0 \\
\hline Total & 13 & & 14 & & 2 & & 29 & 100.0 \\
\hline Note: F = Frequency & & & & & & & &
\end{tabular}


Ng Miew Luan \& Lee Yuen Beng

Table 1(f): National identity issues

\begin{tabular}{lcccccccc}
\hline Month & \multicolumn{2}{c}{ Aug'12 } & \multicolumn{2}{c}{ Sept'12 } & \multicolumn{2}{c}{ Oct'12 } & \multicolumn{2}{c}{ Total frequency } \\
\hline Categories & F & $\mathbf{\%}$ & F & $\mathbf{\%}$ & F & \% & F & \% \\
\hline $\begin{array}{l}\text { News related to national } \\
\text { identity issues }\end{array}$ & 4 & 57 & 1 & 14 & 2 & 29 & 7 & 100.0 \\
\begin{tabular}{l} 
Total \\
\hline
\end{tabular} & 4 & & 1 & & 2 & & 7 & 100.0 \\
\hline
\end{tabular}

Note: $F=$ Frequency

\section{Page Number}

Table 2(a): Cultural rights issues

\begin{tabular}{|c|c|c|c|c|c|c|c|c|}
\hline Month & \multicolumn{2}{|c|}{ Aug'12 } & \multicolumn{2}{|c|}{ Sept'12 } & \multicolumn{2}{|c|}{ Oct'12 } & \multicolumn{2}{|c|}{ Total frequency } \\
\hline Page & $\mathbf{F}$ & $\%$ & $\mathbf{F}$ & $\%$ & $\mathbf{F}$ & $\%$ & $\mathbf{F}$ & $\%$ \\
\hline Front page & 0 & 0 & 0 & 0 & 0 & 0 & 0 & 0 \\
\hline Pages $2 \& 3$ & 6 & 3 & 5 & 3 & 2 & 1 & 13 & 3 \\
\hline $\begin{array}{l}\text { Rest of news } \\
\text { section }\end{array}$ & 160 & 94 & 136 & 95 & 131 & 98 & 427 & 95 \\
\hline $\begin{array}{l}\text { Front page continue } \\
\text { to other pages }\end{array}$ & 5 & 3 & 2 & 1 & 1 & 1 & 8 & 2 \\
\hline Total & 171 & 100 & 143 & 100 & 134 & 100 & 448 & 100 \\
\hline
\end{tabular}

Note: $\mathrm{F}=$ Frequency

Table 2(b): Chinese educational issues

\begin{tabular}{lcccccccc}
\hline Month & \multicolumn{2}{c}{ Aug'12 } & \multicolumn{2}{c}{ Sept'12 } & \multicolumn{2}{c}{ Oct'12 } & \multicolumn{2}{c}{ Total frequency } \\
\hline Page & F & \% & F & \% & F & \% & F & \% \\
\hline Front page & 1 & 1 & 1 & 0 & 3 & 1 & 5 & 1 \\
Pages 2 \& 3 & 47 & 21 & 22 & 9 & 23 & 11 & 92 & 13 \\
Rest of news section & 169 & 76 & 206 & 84 & 180 & 86 & 555 & 82 \\
$\begin{array}{l}\text { Front page continue } \\
\text { to other pages }\end{array}$ & 5 & 2 & 16 & 7 & 4 & 2 & 25 & 4 \\
\hline Total & 222 & 100 & 245 & 100 & 210 & 100 & 677 & 100 \\
\hline
\end{tabular}

Note: $\mathrm{F}=$ Frequency 
Table 2(c): Religious rights

\begin{tabular}{lcccccccc}
\hline Month & \multicolumn{2}{c}{ Aug'12 } & \multicolumn{2}{c}{ Sept'12 } & \multicolumn{2}{c}{ Oct'12 } & \multicolumn{2}{c}{ Total frequency } \\
\hline Page & F & \% & F & \% & F & \% & F & \% \\
\hline Front page & 0 & 0 & 0 & 0 & 0 & 0 & 0 & 0 \\
Pages 2 \& 3 & 1 & 7 & 0 & 0 & 0 & 0 & 1 & 2 \\
Rest of news section & 13 & 93 & 12 & 100 & 26 & 100 & 51 & 98 \\
$\begin{array}{l}\text { Front page continue to } \\
\text { other pages }\end{array}$ & 0 & 0 & 0 & 0 & 0 & 0 & 0 & 0 \\
\hline Total & 14 & 100 & 12 & 100 & 26 & 100 & 52 & 100 \\
\hline Note: F = Frequency & & & & & & & &
\end{tabular}

Table 2(d): Ethnic relationship issues

\begin{tabular}{lcccccccc}
\hline Month & \multicolumn{2}{c}{ Aug'12 } & \multicolumn{2}{c}{ Sept'12 } & \multicolumn{2}{c}{ Oct'12 } & \multicolumn{2}{c}{ Total frequency } \\
\hline Page & F & $\mathbf{\%}$ & F & $\mathbf{\%}$ & F & \% & F & \% \\
\hline Front page & 0 & 0 & 0 & 0 & 0 & 0 & 0 & 0 \\
Pages 2 \& 3 & 0 & 0 & 1 & 7 & 2 & 100 & 3 & 10 \\
$\begin{array}{l}\text { Rest of news section } \\
\text { Front page continue to } \\
\text { other pages }\end{array}$ & 13 & 100 & 13 & 93 & 0 & 0 & 26 & 90 \\
\hline Total & 0 & 0 & 0 & 0 & 0 & 0 & 0 & 0 \\
\hline
\end{tabular}

Note: $\mathrm{F}=$ Frequency

Table 2(e): National identity issues

\begin{tabular}{|c|c|c|c|c|c|c|c|c|}
\hline \multirow{2}{*}{$\begin{array}{l}\text { Month } \\
\text { Page }\end{array}$} & \multicolumn{2}{|c|}{ Aug'12 } & \multicolumn{2}{|c|}{ Sept'12 } & \multicolumn{2}{|c|}{ Oct'12 } & \multicolumn{2}{|c|}{ Total frequency } \\
\hline & $\mathbf{F}$ & $\%$ & $\mathbf{F}$ & $\%$ & F & $\%$ & $\mathbf{F}$ & $\%$ \\
\hline Front page & 0 & 0 & 0 & 0 & 0 & 0 & 0 & 0 \\
\hline Pages $2 \& 3$ & 0 & 0 & 0 & 0 & 0 & 0 & 0 & 0 \\
\hline Rest of news section & 4 & 100 & 1 & 100 & 2 & 100 & 7 & 100 \\
\hline $\begin{array}{l}\text { Front page continue to } \\
\text { other pages }\end{array}$ & 0 & 0 & 0 & 0 & 0 & 0 & 0 & 0 \\
\hline Total & 4 & 100 & 1 & 100 & 2 & 100 & 7 & 100 \\
\hline
\end{tabular}

Note: $\mathrm{F}=$ Frequency 
Ng Miew Luan \& Lee Yuen Beng

\section{Source of News}

Table 3(a): Cultural rights

\begin{tabular}{|c|c|c|c|c|}
\hline Month & Aug'12 & Sept'12 & Oct'12 & Total frequency \\
\hline Source of News & $\mathbf{F}$ & $\mathbf{F}$ & $\mathbf{F}$ & \\
\hline BN Government & 4 & 6 & 7 & 17 \\
\hline $\begin{array}{l}\text { PR Government (Pulau Pinang, } \\
\text { Selangor, Kelantan) }\end{array}$ & 1 & 0 & 0 & 1 \\
\hline Total & & & & 18 \\
\hline $\mathrm{BN}$ - Ruling party & 3 & 0 & 1 & 4 \\
\hline PR - Opposition party & 0 & 2 & 0 & 2 \\
\hline Total & & & & 6 \\
\hline Dong Jiao Zong* & 1 & 0 & 0 & 1 \\
\hline Dong Zong or Dong Lian Hui* & 3 & 0 & 0 & 3 \\
\hline Jiao Zong* $^{*}$ & 2 & 0 & 2 & 4 \\
\hline Hua Zong or Hua Tang* & 6 & 9 & 11 & 26 \\
\hline Xue Hua Tang* & 1 & 2 & 2 & 5 \\
\hline Xiao You Lian Zong* & 0 & 0 & 2 & 2 \\
\hline Chinese guilds and Associations* & 96 & 90 & 80 & 266 \\
\hline Others* & 17 & 12 & 9 & 38 \\
\hline Total & & & & 345 \\
\hline Other ethnic based NGOs & 0 & 0 & 0 & 0 \\
\hline Non-ethnic based NGO & 8 & 7 & 0 & 15 \\
\hline Chinese religious group & 0 & 0 & 0 & 0 \\
\hline Non-Chinese religious group & 0 & 0 & 0 & 0 \\
\hline Editorial & 1 & 0 & 0 & 1 \\
\hline Readers' viewpoints/opinions & 4 & 2 & 7 & 13 \\
\hline Others & 23 & 11 & 12 & 46 \\
\hline Not clear & 1 & 2 & 1 & 4 \\
\hline
\end{tabular}

Notes: $\mathrm{F}=$ Frequency; $\mathrm{BN}=$ Barisan Nasional $; \mathrm{PR}=$ Pakatan Rakyat ${ }^{*}=$ Chinese ethnic $\mathrm{NGO}$ 
Table 3(b): Chinese educational issues

\begin{tabular}{|c|c|c|c|c|}
\hline Month & Aug'12 & Sept'12 & Oct'12 & Total frequency \\
\hline Source of News & $\mathrm{F}$ & $\mathrm{F}$ & $\mathrm{F}$ & \\
\hline BN Government & 23 & 34 & 21 & 78 \\
\hline $\begin{array}{l}\text { PR Government (Pulau Pinang, Selangor, } \\
\text { Kelantan) }\end{array}$ & 2 & 0 & 1 & 3 \\
\hline Total & & & & 81 \\
\hline BN - Ruling party & 13 & 26 & 29 & 68 \\
\hline PR - Opposition party & 1 & 4 & 4 & 9 \\
\hline Total & & & & 77 \\
\hline Dong Jiao Zong* & 0 & 3 & 0 & 3 \\
\hline Dong Zong or Dong Lian Hui* & 40 & 39 & 21 & 100 \\
\hline Jiao Zong* & 4 & 1 & 7 & 12 \\
\hline Hua Zong or Hua Tang* & 15 & 12 & 9 & 36 \\
\hline Xue Hua Tang* & 0 & 1 & 0 & 1 \\
\hline Xiao You Lian Zong* & 2 & 0 & 0 & 2 \\
\hline Chinese guilds and Associations* & 12 & 27 & 7 & 46 \\
\hline Others* & 39 & 38 & 38 & 115 \\
\hline Total & & & & 315 \\
\hline Other ethnic based NGOs & 0 & 1 & 0 & 1 \\
\hline Non-ethnic based NGO & 0 & 2 & 1 & 3 \\
\hline Chinese religious group & 0 & 0 & 0 & 0 \\
\hline Non-Chinese religious group & 0 & 0 & 0 & 0 \\
\hline Editorial & 2 & 2 & 2 & 6 \\
\hline Readers' viewpoints/opinions & 43 & 34 & 36 & 113 \\
\hline Others & 25 & 20 & 33 & 78 \\
\hline Not clear & 1 & 1 & 1 & 3 \\
\hline
\end{tabular}

Notes: $\mathrm{F}=$ Frequency; $\mathrm{BN}=$ Barisan Nasional; $\mathrm{PR}=$ Pakatan Rakyat; $*=$ Chinese ethnic NGO 
Ng Miew Luan \& Lee Yuen Beng

Table 3(c): Religious rights

\begin{tabular}{|c|c|c|c|c|}
\hline Month & Aug'12 & Sept'12 & Oct'12 & Total frequency \\
\hline Source of News & $\mathbf{F}$ & $\mathbf{F}$ & $\mathbf{F}$ & \\
\hline BN Government & 0 & 0 & 1 & 1 \\
\hline $\begin{array}{l}\text { PR Government (Pulau Pinang, } \\
\text { Selangor, Kelantan) }\end{array}$ & 0 & 0 & 0 & 0 \\
\hline Total & & & & 1 \\
\hline BN - Ruling party & 0 & 0 & 0 & 0 \\
\hline PR - Opposition party & 0 & 0 & 0 & 0 \\
\hline Dong Jiao Zong* & 0 & 0 & 0 & 0 \\
\hline Dong Zong or Dong Lian Hui* & 0 & 0 & 0 & 0 \\
\hline Jiao Zong* $^{*}$ & 0 & 0 & 0 & 0 \\
\hline Hua Zong or Hua Tang* & 0 & 0 & 0 & 0 \\
\hline Xue Hua Tang* & 0 & 0 & 0 & 0 \\
\hline Xiao You Lian Zong* & 0 & 0 & 0 & 0 \\
\hline Chinese guilds and Associations* & 0 & 0 & 0 & 0 \\
\hline Dong Jiao Zong* & 0 & 0 & 0 & 0 \\
\hline Other ethnic based NGOs & 0 & 0 & 0 & 0 \\
\hline Non-ethnic based NGO & 0 & 0 & 0 & 0 \\
\hline Chinese religious group & 13 & 7 & 22 & 42 \\
\hline Non-Chinese religious group & 0 & 1 & 0 & 1 \\
\hline Total & & & & 43 \\
\hline Editorial & 0 & 1 & 0 & 1 \\
\hline Readers' viewpoints/opinions & 1 & 1 & 0 & 2 \\
\hline Others & 0 & 2 & 3 & 5 \\
\hline Not clear & 0 & 0 & 0 & 0 \\
\hline
\end{tabular}

Notes: $\mathrm{F}=$ Frequency; $\mathrm{BN}=$ Barisan Nasional; $\mathrm{PR}=$ Pakatan Rakyat $; *=$ Chinese ethnic NGO 
Table 3(d): Ethnic relations issues

\begin{tabular}{|c|c|c|c|c|}
\hline Month & Aug'12 & Sept'12 & Oct'12 & Total frequency \\
\hline Source of News & $\mathbf{F}$ & $\mathbf{F}$ & $\mathbf{F}$ & \\
\hline BN Government & 5 & 6 & 1 & 12 \\
\hline $\begin{array}{l}\text { PR Government (Pulau Pinang, } \\
\text { Selangor, Kelantan) }\end{array}$ & 0 & 1 & 0 & 1 \\
\hline Total & & & & 13 \\
\hline $\mathrm{BN}$ - Ruling party & 2 & 1 & 0 & 3 \\
\hline PR - Opposition party & 1 & 2 & 0 & 3 \\
\hline Total & & & & 6 \\
\hline Dong Jiao Zong* & 0 & 0 & 0 & 0 \\
\hline Dong Zong or Dong Lian Hui* & 0 & 0 & 0 & 0 \\
\hline Jiao Zong* & 0 & 0 & 0 & 0 \\
\hline Hua Zong or Hua Tang* & 0 & 1 & 1 & 2 \\
\hline Xue Hua Tang* & 1 & 0 & 0 & 1 \\
\hline Xiao You Lian Zong* & 0 & 0 & 0 & 0 \\
\hline Chinese guilds and Associations* & 0 & 0 & 0 & 0 \\
\hline Others* $^{*}$ & 0 & 0 & 0 & 0 \\
\hline Total & & & & 3 \\
\hline Other ethnic based NGOs & 0 & 0 & 0 & 0 \\
\hline Non-ethnic based NGO & 0 & 2 & 0 & 2 \\
\hline Chinese religious group & 0 & 0 & 0 & 0 \\
\hline Non-Chinese religious group & 1 & 0 & 0 & 1 \\
\hline Total & & & & 3 \\
\hline Editorial & 1 & 0 & 0 & 1 \\
\hline Readers' viewpoints/opinions & 0 & 0 & 0 & 0 \\
\hline Others & 2 & 1 & 0 & 3 \\
\hline Not clear & 0 & 0 & 0 & 0 \\
\hline
\end{tabular}

Notes: $\mathrm{F}=$ Frequency; $\mathrm{BN}=$ Barisan Nasional; $\mathrm{PR}=$ Pakatan Rakyat $*=$ Chinese ethnic NGO 
Ng Miew Luan \& Lee Yuen Beng

Table 3(e): National identity issues

\begin{tabular}{|c|c|c|c|c|}
\hline Month & Aug'12 & Sept'12 & Oct'12 & Total frequency \\
\hline Source of News & $\mathbf{F}$ & $\mathbf{F}$ & $\mathbf{F}$ & \\
\hline BN Government & 0 & 0 & 1 & 1 \\
\hline $\begin{array}{l}\text { PR Government (Pulau Pinang, } \\
\text { Selangor, Kelantan) }\end{array}$ & 0 & 0 & 0 & 0 \\
\hline Total & & & & 1 \\
\hline BN - Ruling party & 0 & 1 & 1 & 2 \\
\hline PR - Opposition party & 0 & 0 & 0 & 0 \\
\hline Total & & & & 2 \\
\hline Dong Jiao Zong* & 0 & 0 & 0 & 0 \\
\hline Dong Zong or Dong Lian Hui* & 0 & 0 & 0 & 0 \\
\hline Jiao Zong* & 0 & 0 & 0 & 0 \\
\hline Hua Zong or Hua Tang* & 0 & 0 & 0 & 0 \\
\hline Xue Hua Tang* & 0 & 0 & 0 & 0 \\
\hline Xiao You Lian Zong* & 0 & 0 & 0 & 0 \\
\hline Chinese guilds and Associations ${ }^{*}$ & 0 & 0 & 0 & 0 \\
\hline Others* $^{*}$ & 0 & 0 & 0 & 0 \\
\hline Other ethnic based NGOs & 0 & 0 & 0 & 0 \\
\hline Non-ethnic based NGO & 0 & 0 & 0 & 0 \\
\hline Chinese religious group & 0 & 0 & 0 & 0 \\
\hline Non-Chinese religious group & 0 & 0 & 0 & 0 \\
\hline Editorial & 0 & 0 & 0 & 0 \\
\hline Readers' viewpoints/opinions & 4 & 0 & 0 & 4 \\
\hline Others & 0 & 0 & 0 & 0 \\
\hline Not clear & 0 & 0 & 0 & 0 \\
\hline
\end{tabular}

Notes: $\mathrm{F}=$ Frequency; $\mathrm{BN}=$ Barisan Nasional; $\mathrm{PR}=$ Pakatan Rakyat $; *=$ Chinese ethnic NGO 


\section{NEWS SLANT}

Table 4(a): Cultural rights

\begin{tabular}{lcccccc}
\hline Month & \multicolumn{2}{c}{ Aug'12 } & \multicolumn{2}{c}{ Sept'12 } & \multicolumn{2}{c}{ Oct'12 } \\
\hline News Slant & F & $\mathbf{\%}$ & F & \% & F & \% \\
\hline Neutral/balanced & 150 & 88 & 118 & 83 & 120 & 90 \\
Pro cultural rights & 21 & 12 & 25 & 17 & 14 & 10 \\
Against cultural rights & 0 & 0 & 0 & 0 & 0 & 0 \\
\hline Total & 171 & 100 & 143 & 100 & 134 & 100 \\
\hline
\end{tabular}

Note: $\mathrm{F}=$ Frequency

Table 4(b): Chinese educational issues

\begin{tabular}{lcccccc}
\hline Month & \multicolumn{2}{c}{ Aug'12 } & \multicolumn{2}{c}{ Sept'12 } & \multicolumn{2}{c}{ Oct'12 } \\
\hline News Slant & F & \% & F & \% & F & \% \\
\hline Neutral/balanced & 164 & 74 & 158 & 65 & 145 & 69 \\
Pro cultural rights & 57 & 25 & 72 & 29 & 64 & 30 \\
Against cultural rights & 1 & 1 & 15 & 6 & 1 & 1 \\
\hline Total & 222 & 100 & 245 & 100 & 210 & 100 \\
\hline Note: F $=$ Frequency & & & & & &
\end{tabular}

Table 4(c): Religious rights

\begin{tabular}{lcccccc}
\hline Month & \multicolumn{2}{c}{ Aug'12 } & \multicolumn{2}{c}{ Sept'12 } & \multicolumn{2}{c}{ Oct'12 } \\
\hline News Slant & F & \% & F & \% & F & \% \\
\hline Neutral/balanced & 11 & 79 & 11 & 92 & 25 & 96 \\
Pro cultural rights & 3 & 21 & 1 & 8 & 1 & 4 \\
Against cultural rights & 0 & 0 & 0 & 0 & 0 & 0 \\
\hline Total & 14 & 100 & 12 & 100 & 26 & 100 \\
\hline
\end{tabular}

Note: $\mathrm{F}=$ Frequency 
Ng Miew Luan \& Lee Yuen Beng

Table 4(d): Ethnic relations issues

\begin{tabular}{lcccccc}
\hline Month & \multicolumn{2}{c}{ Aug'12 } & \multicolumn{2}{c}{ Sept'12 } & \multicolumn{2}{c}{ Oct'12 } \\
\hline News Slant & F & \% & F & \% & F & \% \\
\hline Neutral/balanced & 1 & 8 & 4 & 29 & 1 & 50 \\
Pro cultural rights & 12 & 92 & 10 & 71 & 1 & 50 \\
Against cultural rights & 0 & 0 & 0 & 0 & 0 & 0 \\
\hline Total & 13 & 100 & 14 & 100 & 2 & 100 \\
\hline Note: $\mathrm{F}=$ Frequency & & & & & &
\end{tabular}

Table 4(e): National identity issues

\begin{tabular}{llccccc}
\hline Month & \multicolumn{2}{c}{ Aug'12 } & \multicolumn{2}{c}{ Sept'12 } & \multicolumn{2}{c}{ Oct'12 } \\
\hline News Slant & F & \% & F & \% & F & $\%$ \\
\hline Neutral/balanced & 2 & 50 & 0 & 0 & 0 & 0 \\
Pro cultural rights & 2 & 50 & 1 & 100 & 2 & 100 \\
Against cultural rights & 0 & 0 & 0 & 0 & 0 & 0 \\
\hline Total & 4 & 100 & 1 & 100 & 2 & 100 \\
\hline Note: F $=$ Frequency & & & & & &
\end{tabular}

Note: $\mathrm{F}=$ Frequency

\section{Picture Used}

Table 5(a): Total number of picture used by different type of news

\begin{tabular}{lccccc}
\hline \multirow{2}{*}{ Types of news } & \multicolumn{2}{c}{ Colour } & \multicolumn{2}{c}{ No colour } & Total \\
\cline { 2 - 6 } & F & $\mathbf{\%}$ & F & \% & F \\
\hline Cultural rights & 361 & 76 & 111 & 24 & 472 \\
Chinese educational issues & 444 & 87 & 64 & 13 & 508 \\
Religious rights & 38 & 86 & 6 & 14 & 44 \\
Ethnic relations issues & 19 & 73 & 7 & 27 & 26 \\
National identity issues & 3 & 100 & 0 & 0 & 3 \\
\hline
\end{tabular}

Note: $\mathrm{F}=$ Frequency 
Table 6(a): Unit of analysis and categories for content analysis and the operational definition

\begin{tabular}{|c|c|c|}
\hline & Unit of analysis & Categories \\
\hline 1. & Newspaper & Sin Chew Daily \\
\hline 2. & Research period & 1 August 2012 to 31 October 2013 \\
\hline \multirow[t]{6}{*}{3.} & Cultural rights & 1. News of local Chinese guilds and associations \\
\hline & & 2. News of local Chinese festivals \\
\hline & & 3. News of local Chinese cultural activities \\
\hline & & 4. News related to Chinese language \\
\hline & & 5. News related to Chinese literature \\
\hline & & 6. News of Chinese literature workshop or competition \\
\hline \multirow[t]{2}{*}{4.} & Chinese education issues & 1. News of local Chinese schools \\
\hline & & 2. News of local Chinese education issues \\
\hline 5. & Religious rights & $\begin{array}{l}\text { 1. News of local Chinese temples } \\
\text { 2. News of local Chinese religious activities (Taoist, } \\
\text { Buddhist, Christian, Muslim, etc.) }\end{array}$ \\
\hline \multirow[t]{2}{*}{6.} & Ethnic relations issues & News related to local ethnic relations issues \\
\hline & & News that promoted good ethnic relations \\
\hline 7. & National identity issues & News related to national identity issues \\
\hline \multirow[t]{4}{*}{8.} & Page & 1. Front page \\
\hline & & 2. Pages 2 and 3 \\
\hline & & 3. Rest of news section \\
\hline & & 4. Front page continue to other pages \\
\hline 9. & Headlines & The news headlines in its original and translation language \\
\hline \multirow[t]{6}{*}{10.} & Source of news & 1. Government \\
\hline & & 1.1 BN (Barisan Nasional) Government \\
\hline & & $\begin{array}{l}\text { 1.2 PR (Pakatan Rakyat) Government (Pulau Pinang, } \\
\text { Selangor, Kelantan) }\end{array}$ \\
\hline & & 2. Political Party \\
\hline & & 2.1 BN (Barisan Nasional) - Ruling Coalition \\
\hline & & 2.2 PR (Pakatan Rakyat) - Opposition Coalition \\
\hline
\end{tabular}


Table 6(a): (continued)

\begin{tabular}{ll}
\hline \multicolumn{1}{c}{ Unit of analysis } & Categories \\
\hline 3. & NGO $(\mathrm{CHN})=$ Chinese Ethnic NGO \\
& 3.1 Dong Jiao Zong \\
& 3.2 Dong Zong or Dong Lian Hui \\
& 3.3 Jiao Zong \\
& 3.4 Hua Zong or Hua Tang \\
& 3.5 Xue Hua Tang \\
& 3.6 Xiao You Lian Zong \\
& 3.7 Chinese Guilds and Associations \\
& 3.8 Others \\
4. & NGO (Other ethnic) $=$ Other ethnic based NGOs \\
5. & NGO (Non ethnic) $=$ Non-ethnic based NG \\
6. & RG = Religious Groups \\
& 6.1 Chinese religious group \\
& 6.2 Non-Chinese religious group \\
7. & Edt = Editorial \\
8. & Rdr/opinion = Readers' viewpoints/opinions \\
9. & Others \\
10. Not clear & 1. Cultural rights \\
1.1 Neutral/balanced & 1.2 Pro cultural rights \\
1.3 Against cultural rights &
\end{tabular}

2. Chinese education issues

2.1 Neutral/balanced

2.2 Pro Chinese education issues

2.3 Against Chinese education issues

3. Religious rights

3.1 Neutral/balanced

3.2 Pro religious rights

3.3 Against religious rights

4. Ethnic Relations Issues

4.1 Neutral/balanced

4.2 Pro ethnic relations issues

4.3 Against ethnic relations issues 
Table 6(a): (continued)

\begin{tabular}{|c|c|}
\hline Unit of analysis & Categories \\
\hline & 5. National identity issues \\
\hline & 5.1 Neutral/balanced \\
\hline & 5.2 Pro national identity issues \\
\hline & 5.3 Against national identity issues \\
\hline \multirow[t]{2}{*}{ 12. Picture } & 1. The number of picture attached with the news report \\
\hline & 2. The picture(s) attached is/are in colour or not in colour \\
\hline
\end{tabular}

\section{Operational Definition}

As shown in Table 6(a), a total of five news themes was identified as the unit of analysis for the content analysis of Sin Chew Daily. The following provides the operational definition of each of the unit analysis and the categories:

1. Newspaper: refers to the name of the publication selected as the research sample in this study, namely Sin Chew Daily which is the largest circulation Chinese daily in Malaysia, with 386,693 circulation in July-December 2012 (Audit Bureau of Circulation Malaysia).

2. Research period: refers to the period of study where news coverage on Cultural rights, Chinese education issues, Religious rights, Ethnic relations issues and National identity issues that were examined. The research period that had been identified is 1 August 2012 to 31 October 2012.

3. Cultural rights: refers to the following news:

3.1 News of the local Chinese guilds and associations - The Malaysian Chinese guilds and association (CGAs) were formed based on the relationship by descent from the common ancestor or family relationship (consanguinity), occupation and geographical origin of the Chinese people in China. The news of all Chinese organiasations that falls into these categories are counted.

3.2 News of local Chinese festivals - This includes news on Chinese New Year celebration, Autumn Festival etc.

3.3 News of local Chinese cultural activities - This includes news about Cultural performances, Chinese martial arts (Wushu), lion dance, Chinese music, Chinese cemetery issues, etc.

3.4 News related to Chinese language - This includes news related to Chinese language or Mandarin (华语) in terms of its usage, its development and so on. 
3.5 News related to Chinese literature - This includes news on calligraphy and books exhibition.

3.6 News of Chinese literature workshop or competition - This includes news to advocate Chinese literature, and the workshops or competition on Chinese literature.

4. Chinese education issues - refers to the news of local Chinese schools and the news of local Chinese educational issues.

4.1 News of local Chinese schools - This includes news on all Chinese primary schools, Chinese independent schools, converted Chinese secondary schools, the three colleges that run by the Chinese community, namely the Han Chiang College, New Era College and Southern College, as well as Universiti Tunku Abdul Rahman (UTAR) and Kolej Tunku Abdul Rahman (TAR Colleges, subsequently upgraded to the status of University colleges in 2013) that run by ruling political party, Malaysian Chinese Association.

4.2 News of local Chinese education issues - This includes the issue of recognition of United Examination Certificate (UEC) by BN government, the issue of teachers' Chinese qualification, the expansion of Chinese independent school, the lack of Chinese teachers in primary, secondary and Chinese independent schools, issue of financial support from the state and Federal governments, the degradation of decision making power by the school committees and the issue of further study opportunities of the Chinese independent schools' students.

5. Religious rights - refers to the minority Chinese religious rights in Malaysia. It is reflected based on the news of local Chinese temples and the news of local Chinese religious activities. This includes news on Chinese Taoist, Buddhist, Chinese Christian and Chinese Muslim and the issue of non-Muslim religious teaching in schools.

6. Ethnic relations issues - refers to news related to the local ethnic relations issues, such as the issues of polarisation and racism as well as the importance of unity, and the news that promotes good ethnic relations.

7. National identity issues - refers to news related to national identity issues such as the issues of citizenship, Chinese identity and national identity.

8. Page - refers to the page number where the news article being studied appeared. There are four categories:

8.1 Front page - News article that published in the front page of the newspaper.

8.2 Pages 2 and 3 - News article that published in page 2 and page 3 of the newspaper. 
8.3 Rest of news section - News article that published in the rest of the news section.

8.4 Front page continues to other pages - News article that published on the front page but continue to other pages.

9. Headlines - refers to the news headlines in its original language. The headlines provides information on the most highlighted issues in Sin Chew Daily according to each news theme identified in this study.

10. Source of the news - refers to the name of the individual(s) or the organisation(s) whose words being quoted in the article. There are tenth categories:

10.1 Government - This is divided into BN government and PR Government (the state of Pulau Pinang, Selangor and Kelantan)

10.2 Political party - This is divided into the BN coalition and the PR coalition.

10.3 Chinese ethnic NGOs - There are divided into eight categories: (1) Dong Jiao Zong, (2) Dong Zong or Dong Lian Hui, (3) Jiao Zong, (4) Hua Zong or Hua Tang, (5) Xue Hua Tang, (6) Xiao You Lian Zong, (7) Chinese Associations and clan associations, and (8) Others (other Chinese ethnic NGOs that is not categorised in [1] to [7]).

10.4 Other ethnic based NGO - This includes the Malay, Indian and other ethnic-based NGOs.

10.5 Non-ethnic based NGO - This included all non-ethnic based NGOs, such as NGOs concerns on environmental issues, human rights issues; the professional associations; student organisations; political parties supporters; labour union etc.

10.6 Religious Groups - This includes the Chinese religious group and nonChinese religious group.

10.7 Editorial - refers to the editorial column of Sin Chew Daily.

10.8 Readers' view point/opinions - refers to the articles published in "Opinion Corner" pages in Sin Chew Daily.

10.9 Others - This includes individuals, school/university authority, police, Sin Chew Daily, the Royal King or family members, private company, etc.

10.10 Not clear - This refers to news articles that do not state the news sources clearly. 
11. News slant - refers to the direction of the news in terms of "Pro", "Neutral" or "Against". There are tenth categories based on each type of news:

11.1 Cultural rights

11.1.1 Neutral/balanced - News that did not support or against Chinese cultural rights and the related issues.

11.1.2 Pro cultural rights - News that supported the Chinese cultural rights and the related issues.

11.1.3 Against cultural rights - News that against the Chinese cultural rights and the related issues.

11.2 Chinese education issues

11.2.1 Neutral/balanced - News that did not support or against the Chinese education issues.

11.2.2 Pro Chinese education issues - News that supported the Chinese education issues.

11.2.3 Against Chinese education issues - News that against the Chinese education issues.

11.3 Religious rights

11.3.1 Neutral/balanced - News that did not support or against the Chinese religious rights.

11.3.2 Pro religious rights - News that supported the Chinese religious rights.

11.3.3 Against religious rights - News that against the Chinese religious rights.

11.4 Ethnic relations issues

11.4.1 Neutral/balanced - News that did not support or against the related ethnic issues and good ethnic relation.

11.4.2 Pro ethnic relation issues- News that supported the related ethnic relation issues and promotes good ethnic relation.

11.4.3 Against ethnic relation issues- News that did not support the related ethnic relation issues and did not promote good ethnic relation.

11.5 National identity issues 
11.5.1 Neutral/balanced - News that did not support or against the related national identity issues.

11.5.2 Pro national identity issues - News that supported the related national identity issues.

11.5.3 Against national identity issues - News that did not support the related national identity issues.

12. Picture - referred to the number of picture(s) attached with the news and colour or non-colour picture(s). 


\section{REFERENCES}

Audit Bureau of Circulations. 2015. Latest audit reports July to December 2015. http:// abcm.org.my/wp-content/reports/2015/jul-15-to-dec-15-newspapers-west-andeast-malaysia-distribution.pdf (accessed 4 November 2016).

Banchoff, T. 2007. Introduction. In Democracy and the new religious pluralism, ed. T. Banchoff, 3-18. New York: Oxford University Press.

Brown, D. 1996. The state and ethnic politics in Southeast Asia. London: Routledge.

Carstens, S. 1988. Chinese publications and the transformation of the Chinese culture in Singapore and Malaysia. In Changing identities of the Southeast Asian Chinese since World War II, eds. G. W. Wang and J. Cushman, 75-95. Hong Kong: Hong Kong University Press.

Chang, P. K, Faridah Ibrahim and C. C. Kuik. 2012. Ethnic media and nation building: Issues, perceptions and challenges. Kuala Lumpur: Universiti Kebangsaan Malaysia.

Chang, T. P. 2005. Huaren shehui, zhongwen baoye yu xinwen ziyou yundong jianlun huashe dui zhongwen baoye de "wenhua shiye qingjie" (华人社会, 中文报业 与新闻自由运动一兼论华社对中文报业的"文化事业情结); Chinese society, Chinese press and the press freedom movement: A discussion on the "Chinese cultural emotional attached" of the Chinese press. https://wami528.wordpress. com/2005/05/29/华人社会, 中文报业与新闻自由运动 (accessed 13 May 2015).

Croteau, D. and W. Hoynes. 2014. Media/society: Industries, images and audiences. 5th ed. California: SAGE Publications Inc.

Department of Statistics Malaysia. 2016. Current populations estimates, Malaysia 2014-2016. https://www.dosm.gov.my/vl/index.php?r=column/cthemeByCat\&cat= 155\&bul_id=OW1xdEVoY1JCS 0hUZzJyRUcvZEYxZz09\&menu id=L0pheU43NWJwRWVSZklWdzQ4TlhUUT09 (accessed 5 November 2016).

Hefner, R. W. 2001. Introduction: Multiculturalism and citizenship in Malaysia, Singapore and Indonesia. In The politics of multiculturalism, pluralism and citizenship in Malaysia, Singapore and Indonesia, ed. R. W. Hefner, 1-58. Honolulu: University of Hawaii Press.

Kua, K. S. 2015. Racism and racial discrimination in Malaysia. Petaling Jaya: Suara Initiatif Sdn. Bhd.

Kou, Y. L. 2005. Hu wenhu baoye wangguo: Cong xingsheng dao shuailuo (胡文虎报业 王国：从兴盛到衰落; The Aw Boon Haw's newspaper empire: The raise and the fall). Petaling Jaya: GB Gerakbudaya Enterprise Sdn. Bhd.

Leong, S. M. Y. 1976. Sources, agencies and manifestations of overseas Chinese nationalism in Malaya, 1937-1941. PhD diss., University of California, Los Angeles.

Ma, L. J. C. and C. L. Cartier. 2003. The Chinese diaspora: Space, place, mobility and identity. America: Rowman \& Littlefield.

Mohd. Dhari Othman. 1992. Malaysian press: A brief account of newspapers published in British Malaya. Malaysian Journal of Communication 8: 117-130. 
Mustafa K. Anuar. 2014. Election advertising in the mainstream print media: Politics for sale during Malaysia's 2013 General Election. Asia Pacific Media Educator 24(1): 77-94. http://ame.sagepub.com/content/24/1/77

Palanca, E. H. 2002. A comparative study of Chinese education in the Philippines and Malaysia. Asian Studies Journal of Critical Perspective on Asia 38(2): 29-62. http://www.asj.upd.edu.ph/mediabox/archive/ASJ-38-2-2002/palanca.pdf (accessed August 2015).

Patel, A. 2010. The survival of a newspaper in the digital age of communication. Undergraduate thesis, New York University. http://www.stern.nyu.edu/sites/ default/files/assets/documents/con_043010.pdf

Peng, W. B. 2005. A study of Chinese newspaper in Southeast Asia. China: Social Sciences Academic Press.

Purcell, V. 1967. The Chinese in Malaya. Kuala Lumpur: Oxford University Press.

Shamsul, A.B. 1999. Identity contestation in Malaysia: A comparative commentary on "Malayness" and "Chineseness". Akademika 55(July): 17-37.

1996. Debating about identity in Malaysia: A discourse analysis. In Southeast Asian Studies 34(3): 476-499.

Siew, N. C. 2008. Duoyuan zhongzu, wenhua he zongjiao shehui zhong, huawen bao de juese. (多元种族、文化和宗教社会中，华文报的角色; The role of the Chinese language newspaper in a multiethnic, multicultural and multi-religion society). In Xinzhou ribao lishi xiezai dama tudi shang (星洲日报历写在大马的土地上 Walking Tall - 80 Years Sin Chew Daily - Journalism on Malaysian soil), ed. N. C. Siew, 271-277. Kuala Lumpur: Sin Chew Daily.

Sim, R. and F. K. Soong. 2007. The three pillars of the Chinese community. http://www. mca.org.my/2/Content/SinglePage? param1=27-032018-85591-03-201827\& param $2=\mathrm{TS}$ (accessed 4 April 2012).

Sinchew-i. 2014. dier jiaozhang: bei zhi fangai tuanjie yanjiu yingfou guanbi huadan xiao (第二教长: 被指妨碍团结. 研究应否关华淡小; Education and Higher Learning Minister II: Ministry to investigate whether to close Chinese and Tamil primary school are said to be obstructing unity). 14 November. http://www. sinchew.com.my/node/1417701 (accessed 5 November 2016).

Statista. n.d. Advertising expenditure in Malaysia from 2008 to 2015, by medium (in million). https://www.statista.com/statistics/386407/advertising-expenditures-bymedium-malaysia/

The United Chinese School Teachers' Association of Malaysia. 2015. Report on the development of SRJK(C) 2000-2014: The schools and the student numbers. http:// web.jiaozong.org.my/doc/2015/jan/2000-2014_sjkc.pdf (accessed April 2015).

UNESCO. 1984. Dynamics of nation-building. Bangkok: UNESCO Regional Office for Education in Asia and the Pacific.

Wang, G. W. 2000. China and the Chinese overseas. Singapore: Times Academic Press.

Wong, J. W. O. 2001. MCA and dailies: Of history, perils and grand strategies. https:// www.malaysiakini.com/news/3283 (accessed 2 March 2007).

Wimmer, R. D. and J. R. Dominick. 2014. Mass media research: An introduction. 10th ed. USA: Wadsworth. 